\title{
The inheritance of tristyly in Decodon verticillatus (Lythraceae)
}

\author{
CHRISTOPHER G. ECKERT* \& SPENCER C. H. BARRETT \\ Department of Botany, University of Toronto, Toronto, Ontario, Canada M5S $3 B 2$
}

\begin{abstract}
The inheritance of tristyly is generally thought to be governed by two diallelic loci, $S$ and $M$, with complete dominance and epistasis between the loci. Significant departures from the two-locus model have, however, been recently reported in species of Oxalis. This study presents a genetic analysis of tristyly in the eastern North American monotypic perennial Decodon verticillatus (L.) Ell. (Lythraceae). Crosses conducted on plants from six natural populations in Ontario resulted in patterns of segregation consistent with the two-locus model. The L morph is homozygous at both loci $(s \mathrm{smm})$. Crosses among $\mathrm{F}_{1}$ progeny identified two $\mathrm{F}_{1}$ individuals of the $\mathrm{M}$ morph homozygous for the dominant allele at the $M$ locus $(s s M M)$ and an $\mathrm{F}_{1}$ individual of the $\mathrm{S}$ morph homozygous for the dominant allele at the $S$ locus $(S S m m)$. Crosses between these genotypes demonstrated epistasis of the $S$ locus over the $M$ locus and produced putative double heterozygotes $(S m / s M)$. Five of these $\mathrm{F}_{2}$ genotypes were both self-fertilized and crossed as pollen donors to individuals of the $\mathrm{L}$ morph. Segregation in $F_{3}$ and backcrossed progenies confirmed the two-locus model and provided no evidence for linkage between the loci. The results support the model of inheritance established for distantly related Lythrum salicaria, suggesting that the genetic control of tristyly may be uniform throughout the Lythraceae.
\end{abstract}

Keywords: Decodon verticillatus, epistasis, linkage, polymorphism, tristyly.

\section{Introduction}

The inheritance of tristyly is generally thought to be governed by two diallelic loci, $S$ and $M$, with complete dominance and epistasis between the loci (Lewis \& Jones, 1992). A dominant allele at the $S$ locus results in expression of the short-styled morph (hereafter $\mathrm{S}$ morph), whereas dominant alleles at the $M$ locus and recessive alleles at the $S$ locus ( $s s M m$ or $s s M M)$ give rise to plants of the mid-styled morph ( $\mathrm{M}$ morph). Recessive alleles at both loci (ssmm) lead to expression of the long-styled morph ( $\mathrm{L}$ morph). Variation on this basic two-locus model can involve polysomic inheritance (Fisher, 1941; Fisher \& Mather, 1943; Weller, 1976), linkage between the loci (Fyfe, 1950) and reversal of the epistatic relationships between the $S$ and $M$ loci (Fyfe, 1956).

Since the model was first proposed for Lythrum salicaria (Lythraceae) by von Ubisch (1926) and later substantiated by Fisher \& Mather (1943), it has been used to explain patterns of inheritance in several tristylous

Correspondence: Department of Biology, Queen's University, Kingston, Ontario, Canada K7L 3N6. species - including members of the other two widely recognized tristylous families, the Oxalidaceae and Pontederiaceae (Fyfe, 1956; Mulcahy, 1964; Sved, 1965; Ornduff, 1972; Weller, 1976; Barrett et al., 1989 and unpublished data). Recently, however, studies on Oxalis species have revealed a more complex genetic system involving a possible third locus, and have confirmed earlier reports of variation in the dominance relationships of alleles at the $S$ and $M$ loci (Leach, 1983; Bennett et al., 1986). The existence of alternative modes of inheritance in closely related groups may have implications for the evolution and maintenance of tristyly (Charlesworth, 1979; Olmstead, 1990; Barrett, 1992). However, the paucity of genetic data from groups besides Oxalis limits our ability to assess whether such variation occurs in other families.

In this study we present a genetic analysis of the inheritance of tristyly in Decodon verticillatus (L.) Ell., an herbaceous, clonal perennial common in wetland habitats throughout eastern North America. The species is the sole member of its genus in the family Lythraceae, possesses a diploid chromosome number $(2 n=16$; Tobe et al., 1986) and, unlike most tristylous species, exhibits a high degree of self- and intramorph- 
compatibility. A controlled crossing programme was undertaken to determine: (i) the number of loci controlling the expression of tristyly; (ii) the dominance relationships among style morph alleles; (iii) whether the loci governing tristyly interact epistatically; and (iv) whether the loci are linked.

\section{Materials and methods}

This study involved three sets of controlled crosses. The first set involved parental stock consisting of 59 plants collected as open-pollinated seed or cuttings from six populations in Ontario, Canada (Table 1). Crosses among $F_{1}$ progeny obtained from these plants (Table 2) identified putative $F_{1}$ homozygotes for each of the style morph loci. Crosses involving these individuals clearly established the dominance relationships among morphs and also produced $\mathrm{F}_{2}$ progeny heterozygous at both loci (Table 3 ). In the final set of crosses, five of these $\mathrm{F}_{2}$ progeny were self-fertilized and crossed as pollen parents to individuals of the $\mathrm{L}$ morph (Table 4).

All crosses were performed in a pollinator-free glasshouse using fine forceps. Flowers were individually tagged and fruits were collected at maturity and stored at $5^{\circ} \mathrm{C}$ for three months before germination. Growth conditions are described by Eckert (1993). Because $D$. verticillatus is a long-lived perennial, only 35-50 per cent of all progeny reached flowering within the duration of the study. However, this is unlikely to have biased segregation ratios since independent glasshouse studies have provided no evidence for differences among morphs in viability or time to flowering.

Statistical analysis of segregation ratios followed the methods of Mather (1963). Hierarchical $\chi^{2}$ analysis was used to assess deviations from expected values as well as heterogeneity among families and reciprocal crosses. Segregation in $\mathrm{F}_{3}$ and backcross (to $\mathrm{L}$ ) progenies was assessed using two orthogonal $\chi^{2}$ tests. Under a two-locus model of inheritance, only one class of recombinant progeny $(\mathrm{sm} / \mathrm{sm})$ will be observed in progenies derived from either selfing or backcrossing double heterozygotes $(\mathrm{Sm} / \mathrm{sM})$, since the other class $(S M / s m)$ is masked by epistasis of the $S$ locus over the $M$ locus. The frequency of the L morph $(\mathrm{sm} / \mathrm{sm})$ in the $\mathrm{F}_{3}$ and backcrosses will depend on both the segregation of the dominant $S$ allele and the segregation of the $M$ versus $m$ alleles. Only the latter is affected by linkage. Total deviation from expected values was, therefore, subdivided into two orthogonal components: one involving segregation at the $S$ locus and the other involving segregation at the $M$ locus.

\section{Results}

All offspring from self and intramorph crosses of the $\mathrm{L}$ morph were $\mathrm{L}$, except for one $\mathrm{M}$ plant presumed to be a contaminant (Table 2). In contrast, similar crosses involving the $\mathrm{M}$ and $\mathrm{S}$ morphs produced segregating progenies, suggesting recessive control of the $\mathrm{L}$ morph.

Table 1 Sources of parental plants used in controlled crosses investigating the inheritance of tristyly in Decodon verticillatus

\begin{tabular}{|c|c|c|c|c|c|}
\hline \multirow[b]{2}{*}{ Population } & \multirow[b]{2}{*}{ Code } & \multirow{2}{*}{$\begin{array}{l}\text { Morphs } \\
\text { present }\end{array}$} & \multirow{2}{*}{$\begin{array}{l}\text { Number of } \\
\text { genotypes } \\
\text { used }\end{array}$} & \multicolumn{2}{|c|}{$\begin{array}{l}\text { Number of crosses } \\
\text { in which parents were }\end{array}$} \\
\hline & & & & Female & Male \\
\hline A. & ON-M6* & $S$ & 4 & 8 & 15 \\
\hline B. & ON-D5 & LM & 6 & 32 & 14 \\
\hline C. & ON-M4 & M & 3 & 2 & 6 \\
\hline D. & EO-T6 & LMS & 23 & 32 & 38 \\
\hline E. & EO-D1 & LS & 21 & 60 & 60 \\
\hline F. & ON-T 7 & LMS & 2 & 3 & 3 \\
\hline
\end{tabular}

Each population, denoted by a single letter, is cross-referenced by a code denoting area of origin $(\mathrm{ON}=$ central Ontario, $\mathrm{EO}=$ eastern Ontario) and morph structure (T, D and $\mathrm{M}=$ trimorphic, dimorphic and monomorphic, respectively). The style morphs present in the population ( $\mathrm{L}, \mathrm{M}$ and $\mathrm{S}=$ long-, mid- and short-styled, respectively) and the number of genotypes used (randomly sampled either as cuttings or open-pollinated seed) are presented along with the number of crosses in which genotypes from a given population acted as female and male parents.

*Electrophoretic studies have indicated that this population consists of a single clonal genotype (Eckert \& Barrett, 1993). 
Excluding the one non-segregating family (E-S34 self), progeny ratios in selfed families from plants of the $S$ morph showed no significant deviation from the 1:3 ratio expected for the segregation of a single dominant factor (L, 19.6 per cent; S, 80.4 per cent, $n=56$ ). Segregation ratios involving $M$ parents generally conformed to the $1: 3$ ratio but showed a marginally signifi- cant $(P=0.056)$ excess in offspring of the $\mathrm{L}$ morph $(\mathrm{L}$, 33 per cent; M, 67 per cent, $n=106$ ) with no significant heterogeneity between selfs and crosses. Crosses between the $\mathrm{L}$ and $\mathrm{M}$ morphs produced 1:1 progeny ratios (L, 50.7 per cent; M, 49.3 per cent, $n=302$ ), with no significant heterogeneity among families or reciprocal crosses. With the exception of a single

Table 2 Segregation of style morphs in crosses among parental plants from natural populations of Decodon verticillatus

\begin{tabular}{|c|c|c|c|c|c|c|c|}
\hline \multirow[b]{2}{*}{ Cross } & \multirow[b]{2}{*}{ Type } & \multicolumn{2}{|l|}{ Parent } & \multicolumn{3}{|c|}{ Proportion } & \multirow{2}{*}{$\begin{array}{l}\text { No. of } \\
\text { progeny }\end{array}$} \\
\hline & & Female & Male & L & M & $\mathrm{S}$ & \\
\hline \multirow[t]{8}{*}{$\mathbf{L} \times \mathbf{L}$} & \multirow[t]{6}{*}{ Self } & B-L1 & self & 1.00 & 0.00 & 0.00 & 35 \\
\hline & & B-L3 & self (F45) & 1.00 & 0.00 & 0.00 & 14 \\
\hline & & B-L6 & self (F49) & 0.98 & $0.02^{*}$ & 0.00 & 55 \\
\hline & & B-L9 & self & 1.00 & 0.00 & 0.00 & 47 \\
\hline & & B-L13 & self & 1.00 & 0.00 & 0.00 & 38 \\
\hline & & Misc. (29) & & 1.00 & 0.00 & 0.00 & 51 \\
\hline & \multirow[t]{2}{*}{ Cross } & Misc. (2) & & 1.00 & 0.00 & 0.00 & 2 \\
\hline & & TOTAL & & 0.996 & 0.004 & 0.00 & 242 \\
\hline \multirow[t]{5}{*}{$\mathrm{M} \times \mathbf{M}$} & \multirow[t]{2}{*}{ Self } & D-M40 & self (F25) & 0.30 & 0.70 & 0.00 & 56 \\
\hline & & Misc. (9) & & 0.38 & 0.62 & 0.00 & 26 \\
\hline & \multirow[t]{3}{*}{ Cross } & D-M40 & D-M2 (F72) & 0.39 & 0.61 & 0.00 & 18 \\
\hline & & D-M2 & D-M40 & 0.17 & 0.83 & 0.00 & 6 \\
\hline & & TOTAL & & 0.33 & 0.67 & 0.00 & 106 \\
\hline
\end{tabular}

Deviation from $1 \mathrm{~L}: 3 \mathrm{M}-\chi^{2}=3.635$, d.f. $=1, P=0.056$

Heterogeneity between self and cross $-\chi^{2}=0.005, d . f .=1, P=0.944$

$\begin{array}{llllllll}\mathrm{S} \times \mathrm{S} & \text { Self } & \text { E-S34 } & \text { self } & 0.00 & 0.00 & 1.00 & 13 \\ & \text { E-S32 } & \text { self(F38) } & 0.15 & 0.00 & 0.85 & 21 \\ & \text { Misc. }(15) & & 0.22 & 0.00 & 0.78 & 35 \\ & \text { TOTAL } \dagger & & 0.20 & 0.00 & 0.80 & 56\end{array}$

Deviation from $1 \mathrm{~L}: 3 \mathrm{~S}-\chi^{2}=0.857$, d.f. $=1, P=0.354$

$\begin{array}{rllllllr}\mathbf{L} \times \mathbf{M} & \text { Cross } & \text { B-L1 } & \text { D-M2 } & 0.46 & 0,54 & 0.00 & 13 \\ & \text { B-L1 } & \text { D-M40 } & 0.52 & 0.48 & 0.00 & 56 \\ & \text { B-L3 } & \text { C-M23 } & 0.67 & 0.33 & 0.00 & 12 \\ & \text { B-L6 } & \text { D-M40 (F54) } & 0.51 & 0.49 & 0.00 & 98 \\ & \text { B-L9 } & \text { D-M40 } & 0.60 & 0.40 & 0.00 & 10 \\ & \text { D-L49 } & \text { D-M2 } & 0.37 & 0.63 & 0.00 & 30 \\ & \text { Misc. (8) } & & 0.45 & 0.55 & 0.00 & 31 \\ & \text { TOTAL } & & 0.50 & 0.50 & 0.00 & 250 \\ & & & & & & \\ \mathbf{M} \times \mathbf{L} \text { Cross } & \text { D-M40 } & \text { D-L37 } & 0.57 & 0.43 & 0.00 & 49 \\ & \text { Misc. (2) } & & 0.33 & 0.67 & 0.00 & 3 \\ & & & 0.56 & 0.44 & 0.00 & 52 \\ & \text { TOTAL } & & 0.51 & 0.49 & 0.00 & 302\end{array}$

Deviation from $1 \mathrm{~L}: 1 \mathrm{M}-\chi^{2}=0.050$, d.f. $=1, P=0.823$

Heterogeneity between reciprocals $-\chi^{2}=0.640, d . f .=1, P=0.424$

Heterogeneity among families within reciprocals $-\chi^{2}=4.360$, d.f. $=6, P=0.628$ 
Table 2 Continued

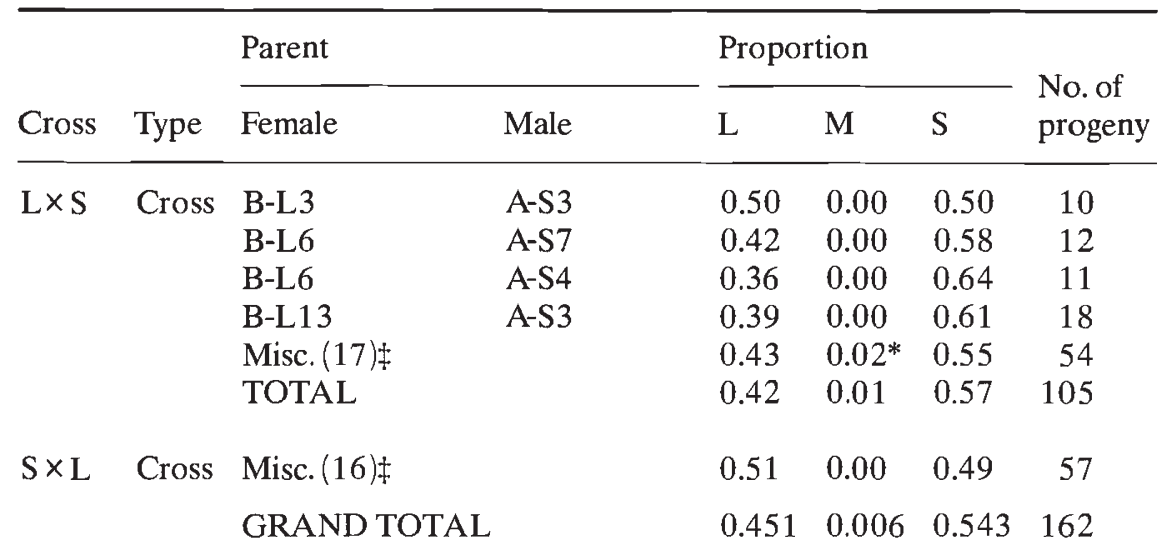

Deviation from 1L : $1 \mathrm{~S}-\chi^{2}=1.397$, d.f. $=1, P=0.237$

Heterogeneity between reciprocals $-\chi^{2}=1.084$, d.f. $=1, P=0.298$

Heterogeneity among families within reciprocals $-\chi^{2}=0.504$, d.f. $=4, P=0.950$

Crosses resulting in families of at least 10 progeny are shown individually; the rest are pooled as miscellaneous, with the number of crosses pooled shown in parentheses. Segregation was observed in 83 per cent of these small families (range $=75-89$ per cent for any given cross type), and the offspring from nonsegregating miscellaneous (misc.) families make up only 3 per cent of the total offspring (range $=1-7$ per cent for any given cross type). Families that provided parental material for second generation crosses are identified in parentheses after the paternal parent (e.g. 'F45'). Segregations marked with an asterisk are assumed to be contaminants, since any other explanation for their infrequent occurrence is inconsistent with the other observed segregations.

$\dagger$ Since the selfed family from E-S34 and other crosses in which it was involved (not shown) did not segregate, data involving this genotype are excluded from the total. $\ddagger$ Nine of the misc. $\mathrm{L} \times \mathrm{S}$ crosses and seven of the misc. $\mathrm{S} \times \mathrm{L}$ crosses involved $\mathrm{S}$ parents from population $\mathrm{A}$, which consists of a single clonal genotype that segregates at the $S$ but not the $M$ locus (see Table 1). The remainder of these misc. crosses involve $\mathrm{S}$ parents from population $\mathrm{E}$, which lacks the $\mathrm{M}$ morph.

offspring of the M morph, presumed to be a contaminant, crosses between the $\mathrm{L}$ and $\mathrm{S}$ morphs also produced equal proportions of $\mathrm{L}$ (45.3 per cent) and S (54.7 per cent) offspring, with no heterogeneity among families or reciprocal crosses.

Crosses among $F_{1}$ progeny identified two individuals ( $F_{1} 72-M 91$ and $\left.F_{1} 25-M 48\right)$ which appeared to be homozygous for the dominant allele at the $M$ locus (putative $S S M M$ ). In both cases, crosses between these genotypes and individuals of the $\mathrm{L}$ morph produced all M progeny $(n=103$; Table 3$)$. In addition, self-fertilization and crosses with individuals heterozygous at the $\mathrm{M}$ locus produced all $\mathrm{M}$ progeny $(n=136)$. Segregation in $\mathrm{F}_{2}$ progenies also identified an individual of the $\mathrm{S}$ morph $\left(\mathrm{F}_{1} 38-\mathrm{S} 47\right)$ which appeared to be homozygous for the dominant allele at the $S$ locus. All crosses involving this individual, including crosses with $\mathrm{F}_{1} 25$ M48, produced only S offspring $(n=173)$.
If tristyly in $D$. verticillatus is controlled by two loci ( $S$ and $M$ ), with $S$ epistatic to $M$, then $\mathrm{F}_{2}$ progeny from crosses between $\mathrm{F}_{1} 38-\mathrm{S} 47$ and $\mathrm{F}_{1} 25-\mathrm{M} 48$ should be heterozygous (in repulsion) at both loci (i.e. $\mathrm{Sm} / \mathrm{sM}$ ). $\mathrm{F}_{1}$ 38-S47 was considered unlikely to have carried a dominant allele at the $M$ locus, since it was produced by self-fertilizing a plant of the S morph (E-S32 in Table 2) originating from a population lacking the $M$ morph (Table 1). In addition, there were no individuals of the $\mathrm{M}$ morph among the 21 offspring from this selfed family. Accordingly, crosses involving offspring from families $F_{2} 112\left(F_{1} 38-S 47 \times F_{1} 25-M 48\right)$ and $\mathrm{F}_{2} 115$ (the reciprocal) were used to investigate the number of loci controlling tristyly and to detect linkage between the loci. Segregation ratios observed for 494 selfed $F_{3}$ and 334 backcrossed offspring showed no major deviation from expectations under the two-locus model, and provided no evidence of linkage between the loci (Table 4). 
Table 3 Segregation of style morphs in Decodon verticillatus; crosses involved three $F_{1}$ genotypes (shown in bold face) suspected of being homozygous at one of the style morph loci

\begin{tabular}{|c|c|c|c|c|c|}
\hline \multicolumn{2}{|l|}{ Parent } & \multicolumn{3}{|c|}{ Proportion } & \multirow{2}{*}{$\begin{array}{l}\text { No. of } \\
\text { progeny }\end{array}$} \\
\hline Female & Male & $\mathrm{L}$ & M & $S$ & \\
\hline \multicolumn{6}{|c|}{ 1. Crosses involving F $\mathbf{7 2 - M 9 1}$ (putative $s M / s M$ ) } \\
\hline F,72-M91 & self & 0.00 & 1.00 & 0.00 & 5 \\
\hline $\mathrm{F}_{1} 45-\mathrm{L} 49$ & $F_{1} 72-M 91$ & 0.00 & 1.00 & 0.00 & 25 \\
\hline $\mathrm{F}_{1} 49-\mathrm{L} 88$ & $F_{1} 72-M 91$ & 0.00 & 1.00 & 0.00 & 12 \\
\hline F,72-M91 & $F_{1} 49-L 88$ & 0.00 & 1.00 & 0.00 & 17 \\
\hline $\mathrm{F}_{1} 54-\mathrm{M} 11^{*}$ & F,72-M91 & 0.00 & 1.00 & 0.00 & 21 \\
\hline F, 72-M91 & $\mathrm{F}_{1} 54-\mathrm{M} 11$ & 0.00 & 1.00 & 0.00 & 26 \\
\hline \multicolumn{6}{|c|}{ 2. Crosses involving $\mathbf{F}_{\mathbf{1}} \mathbf{2 5}$-M48 (putative $s M / s M$ ) } \\
\hline $\mathrm{F}_{1}$ 25-M48 & self & 0.00 & 1.00 & 0.00 & 74 \\
\hline $\mathrm{F}_{1} 49-88 \mathrm{~L}$ & F, 25-M48 & 0.00 & 1.00 & 0.00 & 49 \\
\hline $\mathrm{F}_{1} 25-\mathrm{M} 48$ & $\mathrm{~F}_{1} 54-\mathrm{M} 210$ & 0.00 & 1.00 & 0.00 & 10 \\
\hline$F_{1} 25-M 48$ & F,72-M91 & 0.00 & 1.00 & 0.00 & 18 \\
\hline \multicolumn{6}{|c|}{ 3. Crosses involving $\mathbf{F}_{\mathbf{1}} \mathbf{3 8}-\mathbf{S 4 7}$ (putative $\mathrm{Sm} / \mathrm{Sm}$ ) } \\
\hline$F_{1} 38-S 47$ & self & 0.00 & 0.00 & 1.00 & 2 \\
\hline$F_{1} 38-S 47$ & $\mathrm{~F}_{1} 45-\mathrm{L} 49$ & 0.00 & 0.00 & 1.00 & 15 \\
\hline$F_{1} 38-S 47$ & $F_{1} 49-L 88$ & 0.00 & 0.00 & 1.00 & 23 \\
\hline Mids $\dagger$ & $F_{1} 38-S 47$ & 0.00 & 0.00 & 1.00 & 8 \\
\hline$F_{1} 38-S 47$ & Mids $\dagger^{\dagger}$ & 0.00 & 0.00 & 1.00 & 16 \\
\hline$F_{1} 38-S 47$ & $F_{1} 25-M 48(F 112)$ & 0.00 & 0.00 & 1.00 & 35 \\
\hline F,25-M48 & $\mathbf{F}_{\mathbf{1}} \mathbf{3 8 - S 4 7}(\mathrm{F} 115)$ & 0.00 & 0.00 & 1.00 & 74 \\
\hline
\end{tabular}

${ }^{*} \mathrm{~F}_{1} 54-\mathrm{M} 11$ segregated $\mathrm{L}$ progeny upon being selfed and crossed onto an $\mathrm{L}$ parent. $\dagger$ These data are from crosses using $M$ plants that segregated $L$ progeny in other crosses.

In selfed $F_{3}$ progenies, morph frequencies were very close to those expected for two unlinked loci (expected: L, 6.3 per cent; $\mathrm{M}, 18.7$ per cent; S, 75.0 per cent observed: L, 6.3 per cent; $\mathrm{M}, 16.4$ per cent; $S, 77.3$ per cent). There was no significant deviation from ratios expected for either the $S$ or $M$ locus, and no significant heterogeneity among families. Segregation in backcrossed progenies generally fits the expected ratios (expected: L, 25 per cent; M, 25 per cent; S, 50 per cent - observed: L, 26.9 per cent; $M, 19.2$ per cent; S, 53.9 per cent), with no heterogeneity among families. There was a marginally significant $(P=0.044)$ excess of the $\mathrm{L}$ morph and corresponding deficiency of the $\mathrm{M}$ morph. This particular anomaly was not detected in previous crosses onto the $\mathrm{L}$ morph (Table 2). Power analysis indicated that sample sizes for the $F_{3}$ and backcross progenies were sufficient to detect even a low degree of linkage (i.e. $r=0.48$ ).

\section{Discussion}

Segregation of style morphs in progenies from controlled crosses in $D$. verticillatus indicated that tristyly is governed by two unlinked diallelic loci $(S$ and $M$ ), with $S$ epistatic to $M$. Segregation ratios in progenies from crosses involving plants from natural populations were in accord with the segregation of a single dominant factor at each locus. Crosses involving individuals made homozygous at the style morph loci clearly confirmed the dominance relationships among alleles, and indicated epistasis of the $S$ locus over the $M$ locus. Segregation of all three morphs from crosses involving putative double heterozygotes further demonstrated that inheritance was governed by two loci, with the locus controlling the expression of the $\mathrm{S}$ morph epistatic to a second locus controlling the expression of the $\mathrm{M}$ morph. The frequency of $\mathrm{L}$ offspring in $\mathrm{F}_{3}$ and 
Table 4 Segregation of style morphs in Decodon verticillatus, crosses involved five individuals suspected of being heterozygous at both loci $(\mathrm{Sm} / \mathrm{sM})$

\begin{tabular}{lllllll}
\hline Parent & & \multicolumn{3}{l}{ Proportion } \\
\cline { 1 - 1 } Female & Male & & $\mathrm{L}$ & $\mathrm{M}$ & $\mathrm{S}$ & $\begin{array}{l}\text { No. of } \\
\text { progeny }\end{array}$ \\
\cline { 1 - 1 } Self-pollinations: & & & & & \\
$\mathrm{F}_{2} 112-\mathrm{S} 68$ & self & & 0.06 & 0.11 & 0.83 & 47 \\
$\mathrm{~F}_{2} 112-\mathrm{S} 164$ & self & & 0.06 & 0.16 & 0.79 & 90 \\
$\mathrm{~F}_{2} 115-\mathrm{S} 306$ & self & & 0.05 & 0.15 & 0.80 & 98 \\
$\mathrm{~F}_{2} 115-\mathrm{S} 317$ & seif & & 0.06 & 0.21 & 0.73 & 144 \\
$\mathrm{~F}_{2} 115-\mathrm{S} 340$ & self & & 0.08 & 0.15 & 0.77 & 115 \\
TOTAL & & 0.06 & 0.17 & 0.77 & 494
\end{tabular}

Deviation from $3 \mathrm{~S}: 1$ non-S $-\chi^{2}=1.43$, d.f. $=1, P=0.232$

Heterogeneity among families $-\chi^{2}=2.68$, d.f. $=4, P=0.613$

Deviation from $3 \mathrm{M}: 1 \mathrm{~L}-\chi^{2}=0.39$, d.f. $=1, P=0.533$

Heterogeneity among families $-\chi^{2}=1.32$, d.f. $=4, P=0.857$

Backcrosses to the $\mathrm{L}$ morph:

$\begin{array}{lllllr}\text { E-L60.1 } & \mathrm{F}_{2} 112-\mathrm{S} 68 & 0.11 & 0.22 & 0.67 & 27 \\ \text { E-L51.1 } & \mathrm{F}_{2} 112-\mathrm{S} 164 & 0.24 & 0.20 & 0.56 & 84 \\ \text { D-L36.14 } & \mathrm{F}_{2} 115-\mathrm{S} 306 & 0.32 & 0.17 & 0.51 & 66 \\ \text { D-L12.5 } & \mathrm{F}_{2} 115-\mathrm{S} 317 & 0.26 & 0.15 & 0.59 & 53 \\ \text { D-L18.2 } & \mathrm{F}_{2} 115-\mathrm{S} 340 & 0.31 & 0.21 & 0.48 & 104 \\ \text { TOTAL } & & 0.27 & 0.19 & 0.54 & 334\end{array}$

Deviation from 1S: 1 non-S $-\chi^{2}=2.02$, d.f. $=1, P=0.155$ Heterogeneity among families $-\chi^{2}=3.91$, d.f. $=4, P=0.418$

Deviation from $1 \mathrm{M}: 1 \mathrm{~L}-\chi^{2}=4.05$, d.f. $=1, P=0.044$

Heterogeneity among families $-\chi^{2}=3.14$, d.f. $=4, P=0.534$

Each individual was self-pollinated and backcrossed as a male parent to a plant of the $\mathrm{L}$ morph. Individuals are identified by $F_{2}$ family (e.g. ' $F_{2} 112$ '; see Table 3 ) or population of origin (Table 1), followed by morph (L, M, S) and an identification number.

backcross progenies from plants heterozygous at both loci provided no evidence of linkage between loci. The results support the model of inheritance established for Lythrum salicaria by Fisher \& Mather (1943), except that in L. salicaria inheritance is tetrasomic. Phylogenetic analysis of the Lythraceae (Graham, S. A., Crisci, J. V. and Hoch, P. C., unpub. obs.) suggests that Lythrum and Decodon are rather distantly related genera within the family. This raises the possibility that in contrast to the Oxalidaceae, the genetic control of tristyly may be uniform among the genera (Decodon, Lythrum, Nesaea) that display the polymorphism in the Lythraceae.
The general accord between observed patterns of segregation and expected Mendelian ratios seen in this study is in contrast with results from several other heterostylous taxa in which self- and intramorphcrosses involving the $\mathrm{S}$ morph yielded fewer $\mathrm{S}$ offspring than expected (e.g. Weller \& Ornduff, 1977; Shore \& Barrett, 1985; Barrett et al., 1989). Explanations offered to account for this deviation usually invoke deleterious effects of homozygosity for the dominant $S$ allele or closely linked recessives (Mather \& De Winton, 1941; Schou \& Phillipp, 1983; see also East, 1927). Linkage between the $S$ locus and deleterious recessives may be expected to develop since heterozygosity at the $S$ locus promoted by disassortative mating would shelter nearby mutations from selection (but see Strobeck, 1980). Mather \& De Winton (1941) argued that the development of such linkage has been an important driving force in the evolution of heteromorphic incompatibility. In $D$. verticillatus, however, segregation ratios in self-pollinated $\mathrm{S}$ morph families did not show any indication of reduced viability of $S S$ genotypes. Furthermore, fully viable $S S$ genotypes were identified in $\mathrm{F}_{1}$ progenies. Deleterious effects of homozygosity at the $S$ locus may not occur in $D$. verticillatus because of this species' mating system. Marker gene studies indicate that most populations display significant levels of self-fertilization ( 30 per cent) and low levels of disassortative mating (Eckert, 1993). Accordingly, $S S$ genotypes are likely to be regularly produced in populations, causing closely linked recessive alleles to be exposed to selection.

In contrast to the patterns of inheritance found in the Oxalidaceae (Weller, 1976) and Pontederiaceae (Barrett, S. C. H., unpub. obs.) where the style morph loci appear to be tightly linked, data from $D$. verticitlatus and $L$. salicaria indicate that the $S$ and $M$ loci are unlinked. Tight linkage observed in other tristylous taxa has been viewed as evidence that the $M$ locus may have originated from the $S$ locus via gene duplication and subsequent divergence (Crowe, 1964; Sved, 1965; Richards, 1986; Olmstead, 1990). Gene duplication seems less likely as a mechanism to account for the origin of tristyly in the Lythraceae given that the style morph loci may occur on different chromosomes, or are at least far apart on the same chromosome. Although it is possible to construct molecular scenarios involving gene duplication for the origin of the $M$ locus in the Lythraceae, genetic data from $D$. verticillatus and $L$. salicaria indicate that some other mechanism is more likely to be responsible.

The inheritance of heterostyly involves simple Mendelian segregation of a suite of floral and physiological characters. The segregating factors are generally thought to represent sets of loci, tightly linked in a 
supergene. In distylous taxa, evidence of supergene control has been provided by phenotypes which possess atypical combinations of heterostylous traits that appear to have arisen by crossing-over in the supergene (Ernst, 1955; Dowrick, 1956; Baker, 1966; Shore \& Barrett, 1985; Lewis \& Jones, 1992). The best known examples are the self-fertilizing, homostylous variants in Primula vulgaris (Crosby, 1949).

The possibility of supergene control in tristylous species has, however, been controversial (Charlesworth, 1979; Ganders, 1979; Barrett, 1992; Lewis \& Jones, 1992), largely because possible recombinants have not been clearly identified and analysed genetically. With three different organ levels controlled by two diallelic epistatic loci, it is more difficult to predict the phenotypes of putative recombinants. For example, rare semi-homostylous variants occur in tristylous Lythrum salicaria (Stout, 1925; Esser, 1953); however, the stigma and upper whorl of anthers are positioned mid-way between the usual mid- and long-level anthers. This morphological rearrangement would be unexpected from simple recombination within a tristyly supergene. Semi-homostyles have also been observed in several other taxa, including $D$. verticillatus (Eckert, 1993), and also in Oxalis species (Ornduff, 1972); Eichhornia crassipes (Barrett, 1979); and E. paniculata (Seburn et al., 1990). However, floral variants in these taxa often exhibit considerable quantitative variation in stamen and style length, suggesting that the genes modifying organ positions are non-allelic to the heterostyly genes. Tristyly is associated with self-compatibility and weakly developed pollen heteromorphism in most of these taxa. Hence, identification of floral variants as recombinants is further complicated by the absence of opportunities for concomitant changes in incompatibility reactions and pollen size as occurs in Primula (Richards, 1986). Because of these difficulties, the occurrence of supergenes in tristylous species remains an open question. Application of molecular techniques may prove useful in making further progress towards understanding the evolution of the $S$ and $M$ loci in tristylous plants.

\section{Acknowledgements}

We thank William Cole and Fanny Strumas for technical help, Philip Brailsford, Roland Duffy and Karl Wimmi for horticultural help, and the Natural Sciences and Engineering Research Council of Canada for an operating grant to S.C.H.B. and a postgraduate fellowship to C.G.E.

\section{References}

BAKER, H. G. 1966. The evolution, functioning and breakdown of heteromorphic incompatibility systems. I. Plumbaginaceae. Evolution, 20, 349-368.

BARRETT, S. C. H. 1979. The evolutionary breakdown of tristyly in Eichhornia crassipes (Mart.) Solms (water hyacinth). Evolution, 33, 499-510.

BARRETT, S. C. H. 1992. The evolutionary biology of tristyly. In: Futuyma, D. and Antonovics, J. (eds) Oxford Surveys in Evolutionary Biology, Oxford University Press, Oxford, U.K. (in press).

BARRETT, S. C. H., MORGAN, M. T. AND HUSBAND, B. C. 1989. The dissolution of a complex genetic polymorphism: the evolution of self-fertilization in tristylous Eichhornia paniculata. Evolution, 43, 1398-1416.

BENNETT, J. H., LEACH, C. R. AND GOODWINS, J. R. 1986. The inheritance of style length in Oxalis rosea. Heredity, 56, 393-396.

CHARLESWORTH, D. 1979. The evolution and breakdown of tristyly. Evolution, 33, 486-498.

CROSBY, J. L. 1949. Selection of an unfavourable genecomplex. Evolution, 3, 212-230.

CROWE, L. K. 1964. The evolution of outbreeding in plants. I. The angiosperms. Heredity, 19, 435-457.

DowRICK, V. P. J. 1956. Heterostyly and homostyly in Primula obconica. Heredity, 10, 219-236.

EAST, E. M. 1927. The inheritance of heterostyly in Lythrum salicaria. Genetics, 12, 393-414.

ECKERT, C. G. 1993. The evolutionary maintenance of a sexual polymorphism in clonal Decodon verticillatus (Lythraceae) Ph.D. Thesis, University of Toronto, Canada.

ECKERT, C. G. AND BARRETT, S. C. H. 1993. Clonal reproduction and patterns of genotypic diversity in Decodon verticillatus (Lythraceae). Am. J. Bot., in press.

ERNST, A. 1955. Self-fertility in monomorphic Primulas. Genetica, 27, 391-448.

ESSER, K. 1953. Genomverdoppelung und Pollenschlauchwachstum bei heterostylen. Zeitschrift für Induktive Abstammungs und Vererbungslehre, 85, 28-50.

FISHER, R. A. 1941. The theoretical consequences of polyploid inheritance for the Mid style form in Lythrum salicaria. Ann. Eugen., 11, 31-38.

FISHER, R. A. AND MATHER, K. 1943. Inheritance of style length in Lythrum salicaria. Ann. Eugen., 12, 1-23.

FYFE, V. C. 1950 . The genetics of tristyly in Oxalis valdiviensis. Heredity, 4, 365-371.

FYFE, v. C. 1956. Two modes of inheritance of the short-styled form in the 'genus' Oxalis. Nature, 177, 942-943.

GANDERS, F. R. 1979. The biology of heterostyly. New Zeal. J. Bot., 17, 607-635.

LEACH, C. R. 1983. Fluctuations in heteromorphic self-incompatibility systems. Theor. Appl. Genet., 66, 307-312.

LEWIS, D. AND JONES, D. A. 1992. The genetics of heterostyly. In: Barrett, S. C. H. (ed.) Evolution and Function of Heterostyly, Springer-Verlag, Berlin, pp. 129-150.

MATHER, K. 1963. The Measurement of Linkage in Heredity, 2nd edn, John Wiley \& Sons, New York. 
MATHER, K. AND DE WINTON, D. 1941. Adaptation and counteradaptation of the breeding system in Primula. Ann. Bot., 5, 299-311.

MULCAHY, D. L. 1964. The reproductive biology of Oxalis priceae. Am. J. Bot., 51, 1045-1050.

OLMSTEAD, R. G. 1990. The origin and function of self-incompatibility in flowering plants. Sex. Plant Reprod., 2, 127-136.

ORNDUFF, R. 1972. The breakdown of trimorphic incompatibility in Oxalis section Corniculatae. Evolution, 26, 52-65.

RICHARd, A. J. 1986. Plant Breeding Systems, George Allen \& Unwin, London.

SCHOU, O. AND PHILIPP, M. 1983. An unusual heteromorphic incompatibility system. III. On the genetic control of distyly and self-incompatibility in Anchusa officinalis L. (Boraginaceae). Theor. Appl. Genet., 68, 139-444.

SEBURN, C. N., DICKINSON, T. A. AND BARRETT, S. C. H. 1990. Floral variation in Eichhornia paniculata (Spreng) Solms (Pontederiaceae). I. Instability of stamen positions in genotypes from N. E. Brazil. J. Evol. Biol., 3, 103-123.
SHORE, J. S. AND BARRETT, S. C. H. 1985. Genetics of heterostyly and homostyly in the Turnera ulmifolia complex (Turneraceae). Heredity, 55, 167-174.

STOUT, A. B. 1925. Studies of Lythrum salicaria. II. A new form of flower in the species. Bull. Torrey Bot. Club, 52, 81-85.

STROBECK, C. 1980 . Heterozygosity of a neutral locus linked to a self-incompatibility locus or a balanced lethal. Evolution, 34, 779-788.

SVED, J. A. 1965. Genetical Studies in Tetraploids. Ph.D. Thesis, University of Adelaide, Australia.

TOBE, H., RAVEN, P. H. AND GRAHAM, S. A. 1986. Chromosome counts for some Lythraceae Sens. Str. (Myrtales), and the base number of the family. Taxon, 35, 13-20.

von UBISCH, G. 1926. Koppelung von Farbe und Heterostylie bei Oxalis rosea. Biol. Zentrabl., 46, 633-645.

WELLER, S. G. 1976. The genetic control of tristyly in Oxalis section Ionoxalis. Heredity, 37, 387-393.

WELLER, S. G. AND ORNDUFF, R. 1977. Cryptic self-incompatibility in Amsinckia grandiflora. Evolution, 31, 47-51. 